\title{
Hydrograph Analysis and Hydrological Zones: Tools for Watershed and Water Resources Planning in a Sub Humid Tropical Catchment, Nigeria
}

\author{
I. P. Ifabiyi \\ Department of Geography and Environmental Management, Faculty of Business and Social Sciences \\ P.M.B. 1515, Ilorin, Kwara State, Nigeria \\ E-mail: tokunifabiyi@yahoo.com
}

Received: January 13, 2012 Accepted: January 28, 2012 Published: March 1, 2012

doi:10.5539/jgg.v4n1p183 URL: http://dx.doi.org/10.5539/jgg.v4n1p183

\begin{abstract}
The paper considers the use of hydrological zones derived from runoff hydrographs as planning zones in a Nigerian river catchment. Altogether, 600 hydrographs were separated for 3 flows types for 11years on 20 selected sub basins. The 11 years data were obtained from the Hydrology Department of Kaduna State Water Board, Nigeria between 1979 and 1989. Hydrographs were separated by semi- logarithm method into 3 components of surface flow, interflow and groundwater flow. The Duncan test was used to find if differences exist in the composition and spatial pattern of annual hydrographs in the 20 sub basins of the study area. The results showed that significant differences exist not only in the composition of the different flow types but also from one basin to the other. On the whole, 6 regional patterns emerged for surface and groundwater runoff and 3 patterns for subsurface flow. These regional patterns were proposed as planning zones in the Upper Kaduna Catchment.
\end{abstract}

Keyword: Hydrograph, Watershed, Planning, Development, Tropics

\section{Introduction}

The primary objective of river development planning is effective utilization of water resources within the basin with a view to enhancing development of irrigation agriculture, flood control, improvement of navigation, to enhance provision of water for hydroelectric power development, domestic supply and fishing. The use of drainage basins and indeed hydrographs for planning purposes is quite dated. This is because the drainage basin is interdependent, interconnected, hierarchical and has an orderly arrangement; hence, it is a suitable areal unit for comprehensive and coordinated planning. It therefore implies that, whatever happens at any point in the basin is reflected in both upstream and downstream and thus affects the entire basin. More importantly, most human activities are related to or are influenced by the constraints of the drainage basin system (Strahler, 1964; Knighton, 1984; Jeje and Adesina, 1996; Oyegun, 2007; Jeje, 2007).

Meanwhile, identification of the various development zones could be done via different approaches. Previous studies in Nigeria are dated and have either used basin scale approach (Faniran, 1971), political boundary approach, local basin approach, multi regional basin approach, multinational basin approach (Oyegun, 2007), or even used the evapotranspirative demand of crops to demarcate development units (Olaniran, 1980). Meanwhile, hydrograph analysis and indeed hydrograph separation is seldom been used despite its robustness in such an exercise. Its usage in such context could be quite revealing as it is based on the pathways and sources of runoff components, it is therefore a scientific approach which will provide a clue to runoff characteristics on the basin. The knowledge of such characteristics is very important to watershed management.

The volume of water found as streams can be from three major sources namely: overland flow, subsurface, and groundwater sources. An understanding of these contributions is crucial to the elucidation of catchment behaviour and runoff characteristics. For example, in basins where overland flow dominates runoff will be voluminous in rainy season and such will be prone to flooding, and, or, it may even dry up in the dry season. Therefore, water resources development projects on such basins are better focused on dams and other forms of surface impoundment structures that will conserve the excess seasonal runoff. In basins where groundwater 
component dominate the total hydrograph, such will flow all year round in view of its high dry weather flow and it will be less prone to flooding. In such basins, water resource development should better concentrate on groundwater development. In addition, basins with high sub surface flow will be prone to water logging. This could be harnessed for basin agronomy. Meanwhile, it is through hydrograph analysis that these lucid analyses could be provided as either: political boundary, basin scale analyses or consumptive use approach (Olaniran, 1980) could elucidate these. The hydrograph approach can provide a platform upon which an articulated integrated water resources management plan could be based. Faniran (1971; 1980), Jeje (2007), Oyegun (2007) had earlier proposed such for Nigeria. More importantly, such formed a major discussion in the World Water Report (2009). This present study will propose a watershed management approach based on flow separated hydrographs in the Upper Kaduna Catchment.

\section{Water Resources Development in Nigeria}

A report by Central Bank of Nigeria (2004) showed that $41 \%$ and $51 \%$ of Nigerian populace are children and female respectively, suggesting that relatively high percentage of Nigerians is vulnerable to water borne diseases. Nigeria has a GDP of 1050 dollar and as much as $70 \%$ of the population still lived under 1 dollar daily income. In addition, $32 \%$ of the population are living below $2 / 3$ national mean per capital income. A large percentage of Nigerians $(40 \%)$ are illiterates which may not be able to apply simple hygiene. A report by UNDP (2006) Human Development Index placed Nigeria 159 among 177 countries assessed for availability of safe water. The same report also indicted Nigeria as a bedfellow in a club of 30 nations with the poorest quality of life worldwide.

The above is further complicated when one considers the freshwater resources available in Nigeria. Annual renewable per capita freshwater for Nigeria has been on a decrease. Annual renewable per capita freshwater was $3,203 \mathrm{Cu}$ meters in 1990. This percentage decreased to 1292 cubic meters in 2003 . Indeed about $40 \%$ of Nigerians have no access to safe water and sanitation.

Millions of Nigerians just like in other parts of the developing countries face daily problems in obtaining water for domestic purposes. The coverage of potable water in the country was $20 \%$ in 1980 , this rose to $30 \%$ in 1985 to $35 \%$ in 1991 (Nigeria, 1992) and recently to about 55\% (FOS, 2007). In real terms, the service level in some rural and urban areas in the country is about 10 and 30 liters per capital day (lpcd) respectively (Nigeria, 1992). Hence, people particularly in the rural areas, now resort to various unhygienic sources of water supply like ponds, rivers, rain and hand-dug wells. This is worsened by the frequent breakdown of water infrastructures in the rural areas and the rampant problems of sustainability and serviceability of water infrastructures in Nigerian cities. These are evidenced in the long queues in water points and weeks of dry taps across the nation.

Meanwhile, there are evidences of climate change in Nigeria. This has manifested in form of extreme events such as heavy rainfall within short periods, bouts of dry spells during growing season when certain crops require moisture critically at field capacity, heavy rains when short dry spells are crucial for crop ripening, delay in onset and early retreat of rainfall and shortage in temperature or below or above normal values for specific periods of years (Ojo, et al., 2001; Adesina, 2008; Odekunle, et al., 2008). The evidences produced by the shrinking Lake Chad are another example (Dami, 2008).

All these point to the fact that Nigeria is a water stressed nation, it also call in the same vein for a revision of the approach to water resources management in the country to a more scientific, comprehensive and a well articulated approach that may for now be obtained in hydrograph analysis.

The concept of integrated water resource management has been recently canvassed for in the World Water Report (2009) as a method of achieving the much announced Millennium Development Goal as it relates to provision of adequate water for all uses in the world.

However, previous works in Nigeria have not proposed hydrograph analysis as planning zones despite its relevance to such planning efforts. This is attempted in this study.

\subsection{The Study Area}

The study area is the Upper Kaduna Catchment (UKC) Figure 1. It is located between latitude $9^{0} 11^{`}$ and $3^{0} \mathbf{0 0}$ north and longitude $6^{0} 00$ and $8^{0} 00$ east of the Greenwich Meridian. The climate of the study area is categorized as Koppen $\mathrm{A}_{\mathrm{W}}$ (McKnight, et al. 2000). Tropical wet and dry or savannah climate $(A w)$. These climates have a pronounced dry season, with the driest month having precipitation less than $60 \mathrm{~mm}$ and also less than $(100-$ [total annual precipitation $\{\mathrm{mm}\} / 25])$. In the dry season, cold and dry harmattan wind dominates. The range of temperature is low; it is between $1.67^{\circ}$ and $4.4^{\circ} \mathrm{c}$. January and December are usually the coldest months. Wet season starts in April and end in October. July and August are the wettest months. Around Zaria 67\% of the 
rainfall is experienced in July, August, September, while over 25\% falls in August alone. Rainfall intensity of about $285 \mathrm{~mm} / \mathrm{hr}$ has also been identified. In the southern part of the basin i:e Kogun sub basin rainfall amount is about $1,500 \mathrm{~mm}$ while to the north in Ikara on the Kahugu sub basin rainfall is about $980 \mathrm{~mm}$.

Vegetation is largely the savannah type with tall and scattered trees. In the southern UKC in Kagoro and Assob some riparian forest are found, this may be due to the heavier rainfall $(1,500 \mathrm{~mm})$. The major land uses are: intensively cultivated Sudan savanna, rough savanna landscape and guinea savanna found around the Kogun and Galma basin. In the Kogun basins extensive grazing and dry season farming is practiced. The soils belong to the leached ferruginous soil found under seasonal rainfall, with differentiation in soil horizons and separation of free iron oxide, which forms mottles concretions. Soil aggregation is poor with tendency to compact under wet condition, surface texture is sandy loam. Clay is largely the kaolinite type. The soil is about $30-40 \%$ clayey with depth ( Mortimore, 1970). The Upper Kaduna is largely underlain by the pre Cambrian Basement complex rocks. It is hard and crystalline in nature. Common rock types are younger granite, older granite, schist, migmitite and gneisses complex, recent basalts, etc (Figure 2). Studies have showed that deep regolith are found in many parts of the basin (Offodile, 2000).

The population of the UKC is about 3.9 million (National Population Commission, 2006). Industries include petrochemical, petrol refinery, car assembly, textile, food and beverages, military hardwearing, e.t.c. A few urban settlements are found in the study area such as Kaduna, Zaria, Kafanchan, Kagoro, Saminaka, Zonkwa, etc. A number of water schemes are also found. They include: Kaduna urban water schemes, and other water projects in the local government headquarters in the state. About 411 boreholes were in the state as far back as 1995. A number of irrigation schemes are also in the catchment, prominent are the Maska Irrigation scheme and the Fadama irrigation projects which is found across the Kaduna catchment.

\subsection{Methods of Study}

The data used in this study comprises of data collected from 20 sub basins in the Upper Kaduna Catchment (Figure 1) Nigeria. These data are made up of records of monthly runoff for 11years (1979-1989) based on data availability. Six hundred and sixty hydrographs were separated into 3 components of surface flow; interflow or subsurface flow and base flow. The graphical logarithmic method (Barnes, 1939; Linsley, 1982; Olu, 1995; Mortati, et al. 1997; Hughes, et al., 2003; Nejadhashemi, et al., 2003; Sajumo et al., 2004; Bodie and Hostetler 2005; Gratiot, et. al., 2010) was used to separate the hydrographs (see: a sample of a separated hydrograph of one of the sub basins in this study (River Kogun at Ungwan Rimi) in Figure 3) However, Sujumo, et al. (2004) in a comparative study of different hydrograph separation methods concluded that all the methods showed reasonable and comparable results. Suggesting that with utmost care any of the methods could be used. Meanwhile, it has been discovered that the 2- component hydrograph separation approach should be used with caution as it lumped surface flow with interflow a condition which may lead to misinformation (Ogunkoya and Jenkins, 1991; Ogunkoya and Jenkins, 1993; Jenkins, et. al. 1994). The results obtained were later turned into percentages of total runoff, which in turn form inputs into the Duncan test.

The Duncan multiple range tests was used to establish statistical differences between the runoff components and also in grouping the subbasins based on the level of their contribution to total runoff. The resultant groupings or zones are in form of isoplanes where relative hydrological similarities exist. The isoplanes are proposed as areal units for water resources planning.

\subsection{Presentation of Results}

\subsubsection{Hydrological Zones}

The result of the Duncan test revealed that significant differences exist in the composition of total runoff in the catchment (Tables 1 and 2). Hence, overland flow is dominant accounting for $44.3 \%$ of total runoff, while base flow and interflow accounted for 35\% and 21\% respectively of total runoff. In addition, 6 regional patterns each emerged for surface and groundwater flows, and only 3 regions emerged for interflow (Tables $3 \mathrm{a}, \mathrm{b}$, c, and Figures $4 \mathrm{a}, \mathrm{b}, \mathrm{c})$.

\subsubsection{Zones of Surface Flow}

i. Extremely high: contribution ranges from over $67 \%$ in this zone. Two basins are in this category; they are: Chalwe at Zango Kataf, Kogun at Ugwan Rimi,

ii. High contribution: contribution in this zone ranges from $45 \%$ to $62 \%$. Eight basins are in this category. They are located on Galma, Kachia, Kogun, Assob and Tubo rivers.

iii. Moderately high: Jamana at Soba is the only basin here with $44 \%$ contribution to total runoff. 
iv. Average Contribution: the contribution here range from $35 \%$ to $43 \%$ five basins are found here. Karami at Saminaka has the highest contribution while Kudan at Hunkuyi has the least contribution to total runoff in this group.

v. Low contribution: only three sub basins are found here. . They are: Kogun at Jagindi, Galma at Gubunchi and Kahugu at Ikara.

vi. Extremely low: in this zone, the contribution to total runoff is the least, it is less than $20 \%$, only one basin is found in this class. This again confirms the dominancy of surface flow in this study as most of the basins have surface runoff contribution of at least over $20 \%$.

\subsubsection{Zones of Sub Surface Flow}

The contributions of interflow in the UKC are generally low as it is not greater than $29 \%$ in any of the basins (Table 3 b; Figure4 b).

i. High: Ten basins are in this category; their contribution is between $23.39 \%$ and $28.82 \%$. The highest of them is Karami at Saminaka, while the least in this group is Tubo at Lagos road.

ii. Moderate: Eight basins are found here, and their contribution ranges from $15.5 \%$ to $21.42 \%$. Some of these basins are: Shaho at Kachia, Shika at Kano road, and others. The least contribution is from Kogun at Ugwan Rimi.

iii. Low contribution: contribution here is the least generally low than $13 \%$. Only 2 sub basins are found here. These are: Chalwe at Zango Kataf and Kwassau at Zonkwa.

The pattern exhibited by sub surface flow shows that interflow is generally low in the UKC. It also confirms the seemly uniformity in the pedology of the UKC which is largely ferruginous soil in view of the emergence of only 3 groupings when compared to its counterpart components.

\subsubsection{Zones of Groundwater}

Contribution from groundwater runoff is generally high and also variable. This clearly depicts the pattern of geomorphology of the UKC (Table $3 \mathrm{c}$ and Figure 4c).

i. Extremely high: four basins are in this group; these basins have the highest contributions of groundwater to total runoff. Contributions range from $47.51 \%$ to $59.74 \%$. All these basins are found in the sahelian portion of the Upper Kaduna Catchment.

ii. High: these basins contribute the range from $41.50 \%$ to $42.52 \%$ of groundwater to total runoff. They are: Shika and Hunkuyi which are contagious basins in the sahelian zone.

iii. Moderate: Dorogoin and Gurara at Gatan are in this category with contributions ranging 35.83 to $36.78 \%$. These basins are found in the wetter guinea savanna zone.

iv. Average contribution: contributions of groundwater to total runoff range from 30.79 to $32.65 \%$. Three subbasins are in this zone. Tubo at Kaduna road has the least contribution as low as $30.79 \%$.

v. Low: this is the most dominant group of groundwater contribution; having 6 basins. Assob basin has the highest contribution of $30.44 \%$ while Galma at Ribako has the least of about $26.10 \%$ groundwater contribution.

vi. Extremely low: these sub basins have the least contributions of groundwater; it is generally less than $26 \%$.

The impression from the pattern above shows that the complexities of the nature of weathering and geology played dominant role in the patterns of groundwater as individual basin's contribution do not pattern after climate or any other clearly defined factor.

\subsection{Discussion of Result and Planning Implications}

The pattern depicted by surface flow is a pointer to the basement complex geology and the nature of the surface in the upper Kaduna catchment. The UKC is underlain mainly by crystalline rocks with intensively cultivated land use type which will encourage high surface runoff. The few groupings recorded for subsurface flow was due to the fairly homogeneous nature of soils. Soils in the UKC are $30-40 \%$ clayey. The generally rolling topography in many parts of the catchment will further limit the spatial pattern of subsurface flow. The clayey nature of the soil coupled with the nature of topography will encourage higher soil moisture particularly in the rainy season (Mortimore, 1970). The pattern depicted by groundwater on the other hand is due to the differences and variability in the basal surface of weathering, which has created several pockets of groundwater reserves. A study by Offodile (1990) pointed to the variability of regolith aquifers in Kaduna. Evidences from geophysical 
investigations in many parts of the pre Cambrian Basement Complex rocks of Africa, especially in Nigeria and South Africa have pointed to large reserves of groundwater in basins of decomposition, joints and fissures which are created by deep chemical weathering (Faniran, et al. and Enslim, 1943). These basins of decomposition consist of elastic rocks with high rates of water ingress during raining seasons.

The patterns of contribution of the three flow types to total runoff signal to some underlying factors controlling annual total runoff in the UKC. As shown in Table 1 large sub basins tend to have high contribution of surface runoff to the hydrographs, for example, Kogun at Ugwan Rimi, Galma at Kuzuntu, Galma at Ribako, Tubo at Lagos road, etc have high surface flow contributions. This agrees with the findings of Anyadike and Phil-Eze (1989) that basin size is a determinant of runoff. The impact of rainfall is also quite significant. This is because basins in wetter latitudes such as Chalwe at Zango Kataf and Kogun at Ugwan Rimi in the south of latitude $10^{\circ}$ $\mathrm{N}$ have higher rainfall and high surface flow contributions despite the fact that they are not as large as some others basins. For example, Karami at Kauru which is located within the zone of least rainfall, despite its size, has the least contribution of surface flow. NEDECO (1959) and Ledger, (1964; 1969) confirmed that runoff in West Africa respond sharply to precipitation events.

In addition, the geology, nature of the surface and the soil also play significant roles in the explanation of runoff response pattern in the study area. The Upper Kaduna Catchment is dominated by crystalline rocks of basement complex, undifferentiated granite and rock outcrops are also common features. This factor partly explains the percentage groundwater contribution from Assob basin which is $50 \%$ located on rock outcrop and on younger granite. In addition to other forms of crystalline rocks in the study area, quartzite form about $19 \%$ of the geology. Quartzite is a hard metamorphic rock which was originally a sandstone rock, but changed through the processes of metamorphism to quartzite. The quartzite areas which also coincide with areas of forests are zones of water ingress in the UKC. The areas of forests and granite have been found to have significant contribution of groundwater. Kogun at Jagindi, Galma at Gubunchi, Tubo basin, Chalwe, Dorogoin, and Gurara are typical examples. Ogunkoya, et al. (1984) reported similarly in south western Nigeria that basin geology particularly the percentages of forest and quartzite play important role in dry season runoff in the Owena river basin. The role of soil can be underscored particularly in the sub basins in the extreme north of the study area where rainfall is least. These basins have the highest groundwater contributions particularly: Karami at Kauru and Kahugu at Ikara where aeolian deposit emanating from years of Harmattan haze has modified top soil into porous silt soil.

The signature of land use is also discernable in the study area as areas of high overland contribution coincide with areas of intensively cultivated areas. For example all the basins with contribution of above $35 \%$ of surface flow are intensively cultivated and grazed (Table $3 \mathrm{a}$ ). The UKC is a closely settled zone with high rural population density, particularly the areas north of latitude $10^{\circ} \mathrm{N}$. Hence, lands are intensively cultivated with patches of fallow land in-between them forming scrub and grazing areas. Lal (1980); Pereira, (1973), Bosch and Hewlett, (1984), Sighn, (2001), Wiles-Skeels, et al. (2004) and Hovat et al. (2006) have all reported that the nature of the soil surface and land use have effects on runoff. While Odemirho, (1984 a\&b) also reported that cultivation affect stream flow and channel morphology in southern Nigeria.

The gentle terrain of most part of the UKC coupled with its large basin sizes have provided extensive water logged flood plains in major subbasins such as Galma, Tubo, Karami and Kogun basins, which have now formed large area of dry season farming in the basin. These basins have high contributions of interflow. These areas also form runoff source areas and they are extensively and intensively cultivated for dry season farming. Anyadike and Phil-Eze (1979) equally identified channel steepness and basin altitude as important factors to response of total runoff in Nigeria.

The patterns above have several implications for watershed management. The first is that emphasis should be made to develop surface water in many of the sub basins of the study area, as surface flow generally form a higher percentage of total runoff in about half of the basins. It is greater than $35 \%$ contribution in 16 of the 20 subbasins in the study area (Table 3a). Hence, a comprehensive inter basin water scheme can be designed to involve micro and medium scale dams. These dams are cheaper to construct and have limited environmental impacts. They could be used to harness the abundant surface water resources that is been allowed to waste annually. It could be used harmoniously to service water needs in the 6 months of dry seasons in the Upper Kaduna Catchment. Micro dams are generally more environmental friendly, they have low maintenance rate and they require minima initial cost. The Chinese experience is a beautiful lesson here, where over 1000 micro dams were involved in harnessing water power resources; an effort which has gone a long way to resolving the water needs in China particularly in the power sector. Hence, from the zone of average contribution of overland flow to extremely high contribution where surface flow is contributing $35 \%$ to $67 \%$ emphasis should be on surface water development, this seasonally excess surface water is in abundance in the rainy season but it is left to drain away 
or to flood annually, only for the communities to face water scarcity problems in the dry season. The dams would also reclaim hitherto seasonally flooded lands in rainy season for farming during rainy season.

The second notable lesson is that groundwater can also supplement water supply or form a major source of water supply in more than $50 \%$ of subbasins. For example, contribution of groundwater to total runoff is over $30 \%$ in 13 of the 20 sub basins (Table $3 b$ ). For example, in basins with above $35.83 \%$ contributions, which are categorized as moderate contribution, high contribution and extremely high contributions; rather than focusing entirely on surface water development for water use, groundwater could form a conjunctive source of water in these sub basins. It should be noted that Upper Kaduna basin has a high rural population density and many scattered rural settlements. Boreholes would serve as an important tool in intervening in the water resource needs of these numerous and dispersed rural communities. Groundwater is available at the point of demand, it is cheap to construct, it is of higher quality, its development does not require large land area, its development do not lead to resettlement and peoples' displacement also no aquatic environment is created as results of its development.

Thirdly, the pattern depicted by subsurface flow can form crop zones for agriculture production. Efficiency will be enhanced if crop specialization based on crop water requirement is pursued in agricultural production and management. Indeed, Olaniran (1980) had earlier proposed a similar thing based on the concept of evapotranspiration for the Niger basin area of Nigeria. Areas of high subsurface flow contribution otherwise categorized as high contribution zone ranging from $23.39-28.82 \%$ will have the potential for the cultivation of water bearing plants such as rice, sugarcane, etc, while those with moderate contributions would have the potential to produce less water bearing plants like maize, guinea corn, cassava, yams. Lastly, low water bearing crops would be of better potential in the low contribution areas. Indeed, crop specialization will lead to productivity.

\section{Conclusion}

The above have clearly showed that the pre Basement Complex rocks of the upper Kaduna basin can be rich in water resources. However, with appropriate management techniques this water resource can be harnessed for various uses; particularly agricultural production. Further, the use of appropriate techniques will also suggest the most efficient methodology for harnessing the waters of the basement complex rocks. Hydrograph analysis can remain a veritable tool in achieving sustainable development in agricultural production. Sustainable agriculture remains a panacea for resolving the growing unemployment among able-bodied youths in Nigeria; this will further enhance peace and security in Nigeria.

\section{References}

Adesina, F. A. (2008). Living a severely altered world Inaugural Lecture Series 218. Delivered at Oduduwa Hall Obafemi Awolowo University, Ile-Ife $26^{\text {th }}$ October , 2008. Press, Ile-Ife, Nigeria.

Anyadike, R. N. G. \& Phil-Eze, R. N. (1989). Runoff response to basin parameters in south eastern Nigeria. Geografiska Annaler, 71A(1-2), 75-84. http://dx.doi.org/10.2307/521009

Barnes, B. S. (1939) The structure of discharge recession curves. Transactions of the American Geophysical UNION, 20, 721-725.

Bodie, R. S. \& Hostetler, S. (2005). A review of techniques for analysing base flow from stream hydrographs Proceedings of the NZHS-IAHZSS 2005 Conference $28^{\text {th }}$ November $-2^{\text {nd }}$ December Auckland, 2005.

Bosch, J. M. \& Hewlett, J. D. (1984). A review of catchment experiments to determine the effects of vegetation changes on west water yield and evapotranspiration. Journal of Hydrology, 39, 3-33.

Dami, A. (2008). A predictive study of environmental change in the Nigeria's section of the Chad basin. Unpublished P.hD. Thesis. Obafemi Awolowo University, Ile-Ife.

Faniran, A. (1977). The use of drainage basins in development planning in West Africa. Nigeria Geographical Journal, 20(2), 189-197.

Faniran, A. (1982). River basin development authorities: a strategy for rural development in Nigeria. Silver Jubilee Conference of the Nigerian Geographical Association University of Ibadan, Summaries of Paper.

Faniran, A. (1985). Conjunctive water use: a strategy for water supply in developing countries. Journal of Nigerian Institute of town Planners, 4(1), 107-118.

Gratiot, N. C. Duvert, L. Collect, D. et al. (2010). Increase in surface runoff in the central mountain of Mexico: Lessons from the past and predictive scenario for the next century. Hydrology Earth System Sciences, 14, 291-300. http://dx.doi.org/10.5194/hess-14-291-2010 
Horvat, O. et al. (2006). Geophysical assessment of land use change impact on runoff with a hydrological model with a distributed parameters. Geophysical Research Abstracts, 8, 07419.

Hughes, D. A., Hannart, P. \& Watkins, D. (2003). Continuous base flow separation from time series of daily and monthly stream flow data". Water $S A, 29(1), 43-48$.

Irwin, F. \& William, I. R. (1986). Catchment as planning units. Soil conservation service N.S.W., 40, 6-10.

Jeje, L. K. \& Adesina, F. A. (1996). Man Environment an Introductory Note. Research Evaluation Resources and Development Consultancy Ede, pp218.

Jeje, L. K. (2007). Drainage basin development and the environment in Geographical Perspectives On Environment Problems And Management In Nigeria. Ofomata, G. E. K. and Phil-Eze, P. O., Jamoe, Publ., Enugu.

Jenkins, A., Ferrier, R. C., Harriman, R. et al. (1994). A case study in catchment hydrochemistry: conflicting interpretation from hydrological and chemical observation. Hydrological Processes, 8, 335-349. http://dx.doi.org/10.1002/hyp.3360080406

Knighton, A. D. (1984). Fluvial Forms and Processes. London: Arnold. Pp218.

Ledger, D. C. (1964). Some hydrological characteristics West African rivers. Institution of British Geographers.

Ledger, D. C. (1969). The dry season characteristics of west Africa rivers in M.F. Thomas and G.W. Whittington (eds) Environment and Land Use in Africa. Methuen. pp.88-102.

McKnight, Tom L., \& Hess, Darrel. (2000). Climate Zones and Types: The Köppen System. Physical Geography: A Landscape Appreciation. Upper Saddle River, NJ: Prentice Hall.

Mortathi, J. J., M. Moraes, \& J. C. Rodriguez (Jr). (1997). Hydrograph separation of the Amazon river using ${ }^{18} \mathrm{O}$ as an isotopic tracer. Scienta Agricola, 554(3).

Mortimore, M. J. (1970). (ed.) Zaria and Its Region. Department of Geography Ahmadu Bello University Occasional Paper. No 4. Ahmadu Bello University Zaria, Nigeria.

NEDECO (Netherlands Engineering Consultants). (1959). River studies and recommendation on improvements of Niger and Benue. North Holland Pub. Co. Amsterdam. 1000pp.

Nejadhasheni, A. P., Shirmohammadi, A. \& Montas, H. J. (2003). Evaluation of stream flow partioning methods. Paper Number 032183,2003.ASAE Annual Meeting. American Society of Agriculture and Biological Engineers.

Odekunle, T. O., Andrew, O. \& Aremu, S. O. (2008). Towards a wetter Sudano sahelian ecological zone in the twenty first century Nigeria. Weather, 63, 66-70. http://dx.doi.org/10.1002/wea.172

Odemirho, F. O. (1984a). A reduced rank production model on stream channel response to traditional land use $\begin{array}{llllll}\text { practices in southwest Nigeria. Journal of Hydrology, 70, 85-100. } & \text {. }\end{array}$ http://dx.doi.org/10.1016/0022-1694(84)90115-X

Odemirho, F. O. (1984b). The effects of shifting cultivation on stream channel size and hydraulic geometry in small headwater basin in south western Nigeria. Geografiska Annaler, 66A(4), 337-340.

Ogunkoya, O. O. \& Jenkins, A. (1991). Analyses of storm runoff pathways using deuterium and stream chemistry. Hydrological Processes, 5, 271-282. http://dx.doi.org/10.1002/hyp.3360050307

Ogunkoya, O. O., Adejuwon, J. O. \& Jeje, L. K. (1984). Runoff response to basin parameters in south western Nigeria. Journal of Hydrology, 72, 67-84. http://dx.doi.org/10.1016/0022-1694(84)90185-9

Olu, O. E. A. (1986). Evaluation of direct recharge in the Sokoto-Rima basin Nigeria. Unpublished M.Sc Thesis Department of Civil Engineering ABU Zaria.

Oyegun, R. O. (2007). Environmental problem of water resources development. A geographical perspective. in Geographical Perspective On Environmental Problem And Management In Nigeria. Jamoe publ. Enugu.

Singh, R. B. (2001). Impact of land use change on groundwater in the Punjab-Haryana plains, India. IAHS publ, 269, 117-121.

Strahler, A. N. (1964). Quantitative geomorphology of drainage basin and channel networks. in (ed) V.T. Chow , Handbook of Applied Hydrology. McGraw Hill, New York Section 4-11.

Sujumo, J., Shikado, S., \& Hiramatsu, K. (2004). A comparison of techniques for hydrograph recession analysis. Hydrological Processes, 18(3), 403-413. http://dx.doi.org/10.1002/hyp.1247 
Wiles-Skeels, Robin, H. \& Nicholas, K. K. (2004). Evaluating the effects of land use on peak discharge and runoff in the Saratoga Lake watershed. Geological Society of America Abstracts, 36(2), 127.

Table 1. Duncan Test Showing Differences in the Three flow types

\begin{tabular}{|l|l|l|l|l|l|}
\hline Flow types & Df & ANOVA Sum of Square & Mean Square & F-Value & PR $>$ F \\
\hline Differences in runoff components & 2 & 55862 & 27931 & 101 & 0.001 \\
\hline
\end{tabular}

Table 2. Duncan Test Showing Differences in the Flow Type Contribution from One Sub Basin to the Other

\begin{tabular}{|c|l|l|l|l|l|}
\hline Flow types & Df & ANOVA sum of square & Mean square & F-Value & PR>F \\
\hline 1. Surface runoff & 19 & 3877 & 204 & 2.36 & 0.0018 \\
\hline 2. Groundwater & 19 & 24186 & 1273 & 6.26 & 0.0001 \\
\hline 3. Interflow & 19 & 31475 & 1557 & 6.00 & 0.001 \\
\hline
\end{tabular}

Table 3a. Surface runoff Contribution to total runoff

\begin{tabular}{|c|c|c|}
\hline sub basin & Percentage contribution & Remarks \\
\hline $\begin{array}{l}\text { 1.Chalwe at Zango Kataf } \\
\text { 2. Kogun at Ugwan Rimi }\end{array}$ & $\begin{array}{l}67 \\
67\end{array}$ & Extremely high \\
\hline $\begin{array}{l}\text { 3. Galma at Kuzuntu } \\
\text { 4. Kwassau at Zonkwa } \\
\text { 5. Galma at Ribako } \\
\text { 6. Kachia at Kachia } \\
\text { 7. Shaho at Kachia } \\
\text { 8. Kogun at Kagoro } \\
\text { 9. Assob at Assob } \\
\text { 10. Tubo at Lagos road }\end{array}$ & $\begin{array}{l}62 \\
60 \\
50 \\
48 \\
47 \\
46 \\
46 \\
45\end{array}$ & High \\
\hline 11. Jamana at Soba & 44 & Moderately high \\
\hline $\begin{array}{l}\text { 12. Karami at Saminaka } \\
\text { 13. Dorogoin at Kwoi } \\
\text { 14. Gurara at Gatan } \\
\text { 15. Shika at Kano road } \\
\text { 16. Kudan at Hunkuyi }\end{array}$ & $\begin{array}{l}43 \\
39 \\
39 \\
36 \\
35 \\
35\end{array}$ & Average contribution \\
\hline $\begin{array}{l}\text { 17. Kogun at Jagindi } \\
\text { 18. Galma at Gubunchi } \\
\text { 19. Kahugu at Ikara }\end{array}$ & $\begin{array}{l}30 \\
30 \\
29\end{array}$ & Low contribution \\
\hline 20. Karami at Kauru & 20 & Extremely Low \\
\hline
\end{tabular}


Table 3b. Interflow contribution to total runoff

\begin{tabular}{|l|l|l|}
\hline Sub basins & Percentage Contribution & Remarks \\
\hline 1.karami at Saminaka & 28.82 & High \\
2. Jamana at soba & 26.09 & \\
3. Kachia at Kachia & 25.50 & \\
4. Kogun at Kagoro & 24.59 & \\
5. Gurara at Gatan & 24.58 & \\
6. Assob at Assob & 24.53 & \\
7. Karami at Kauru & 23.86 & \\
8. Dorogoin at Kwoi & 23.82 & \\
9. Kudan at Hunkuyi & 23.42 & Moderate \\
10. Tubo qt at Lagos road & 23.39 & \\
\hline 11. Shaho at Kachia & 21.42 & \\
12. Shika at Kano road & 21.11 & \\
13. Galma at Ribako & 20.92 & \\
14. Galma at Gubunchi & 19.83 & \\
15.kogun at Jagindi & 18.44 & \\
16. Galma at Kuzuntu & 17.85 & \\
17. Galma at Ikara & 16.95 & \\
18. Kogun at Ugwan Rimi & 15.52 & \\
\hline 19. Chalwe at Zango Kataf & 12.62 & \\
20. Kwassau at Zonkwa & 11.98 & \\
\hline
\end{tabular}

Table 3c. Groundwater contribution to total runoff

\begin{tabular}{|c|l|l|}
\hline Sub basin & Percentage contribution & Remarks \\
\hline 1. Karami Kauru & 59.74 & Extremely high \\
2. Kahugu at Ikara & 53.92 & \\
3. Kogun at Jagindi & 51.00 & \\
4. Galma at Gubunchi & 47.51 & \\
\hline 5. Shika at Kano road & 42.52 & High contribution \\
6. Kudan at Hunkuyi & 41.50 & \\
\hline 7. Dorogoin at Kwoi & 36.78 & moderate \\
8. Gurara at Gatan & 35.83 & \\
\hline 9. Chalwe at Zango Kataf & 32.65 & average \\
10. Shaho at Kachia & 31.34 & \\
11. Tubo at Lagos road & 30.79 & low \\
\hline 12. Assob at Assob & 30.64 & \\
13. Kogun at Kagoro & 30.22 & \\
14. Jamana at soba & 29.90 & \\
15. Kogun at Ugwan Rimi & 29.58 & \\
16. Karami at Saminaka & 29.18 & \\
17. Galma at Ribako & 26.10 & \\
18. Kachia at Kachia & 25.69 & \\
19. Galma at Kuzuntu & 18.38 & \\
20. Kwassau at Zonkwa & 16.97 & \\
\hline
\end{tabular}




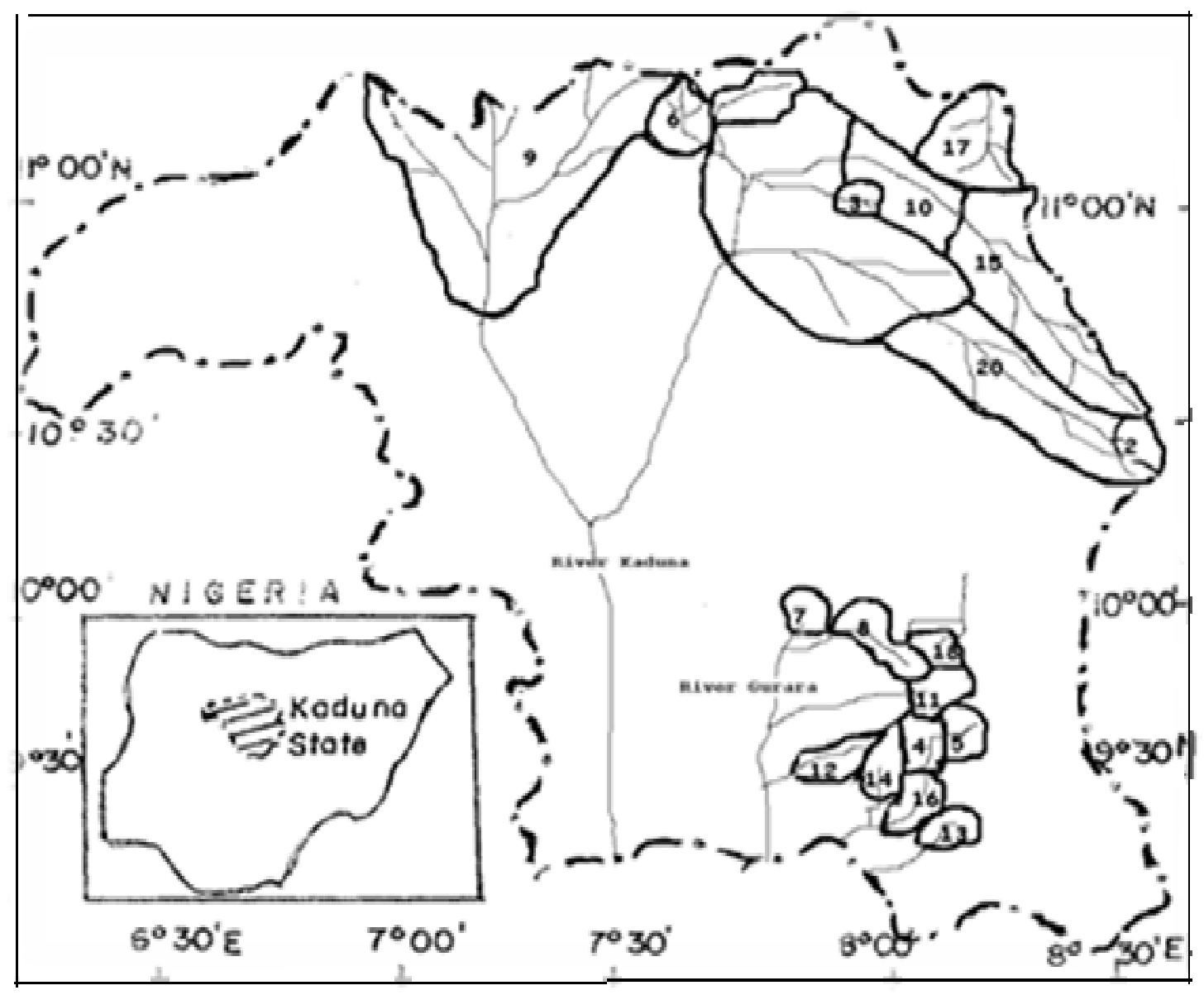

Sub basins of the Upper Kaduna basin, Nigeria

1.Galma At Gubunchi

2.Karami At Saminaka

3.Jamana At Soba

4.Kogun At Kagoro

5.Kogun At Ungwan Rimi

6.Shika At Kano Road

7.Shaho At Kachia

8.Kachia At Kachia

9.Tubo At Lagos Road

10.Galma At Gubunchi
11.Chalwe At Zango Kataf

12.Gurara At Gatan At Zonkwa

13. Assob At Assob

14.Dorogoin At Dorogoin

15.Galma At Kuzuntu

16.Kogun At Jagindi

17.Kahugu At Ikara

18.Kwassaua At Zonkwa

19.Kudan At Hunkuyi

20.Karami At Saminaka

Figure 1. Upper Kaduna Catchment and its sub basins 


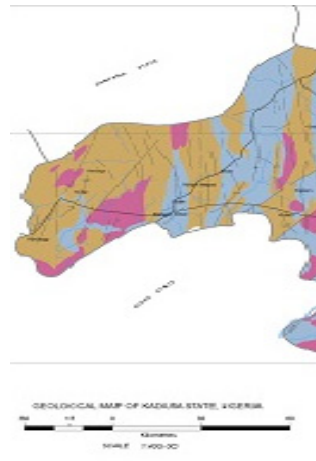

$9^{\mathrm{O}} 00 \mathrm{~N}$
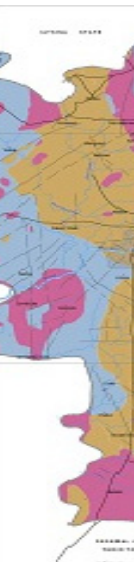

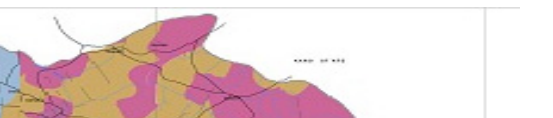

\section{Explanations}

- Towns

Roads

--1- Ring Complexes

Fault/Fracture

Rivers

Major Towns

_- State Boundary

Tertiary-Recent Basalts

Younger Granite Series

Pan-Afrcan Older Granite

Metasediment (Schist)

Migmatite-Gneiss Complex

$\begin{array}{lll}7^{\mathrm{O}} 00 \mathrm{E} & 8^{\mathrm{O}} .00 \mathrm{E} & 9^{\mathrm{O}} .00 \mathrm{E}\end{array}$

Figure 2. Geological Map of the kaduna basin, Nigeria

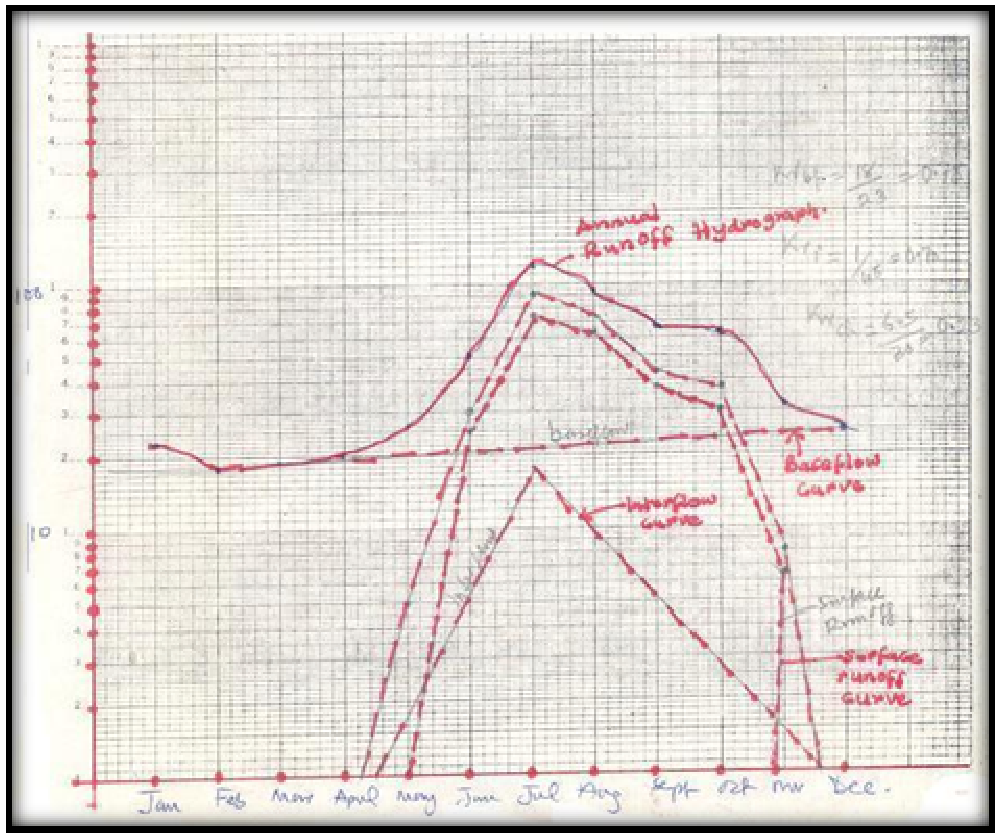

Figure 3. A typical Separated Hydrograph of Kogun at Ungwan Rimi 


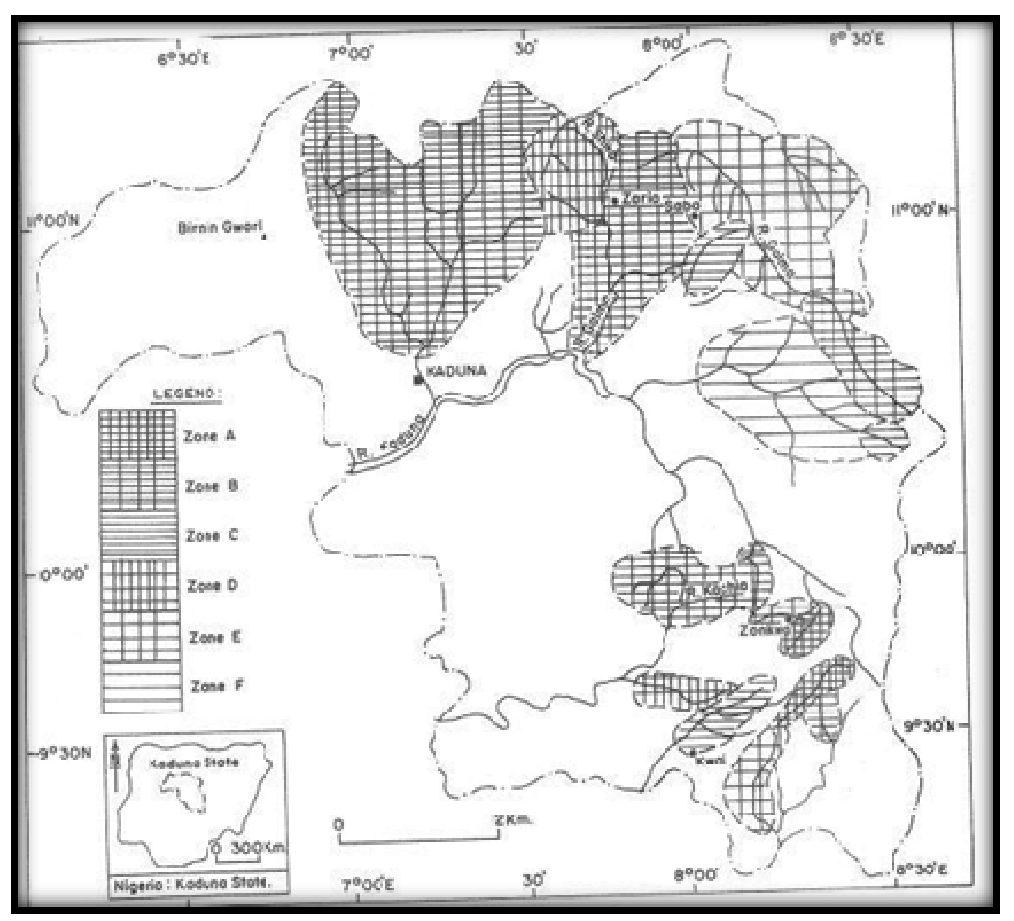

Figure 4a. Pattern of Surface flow

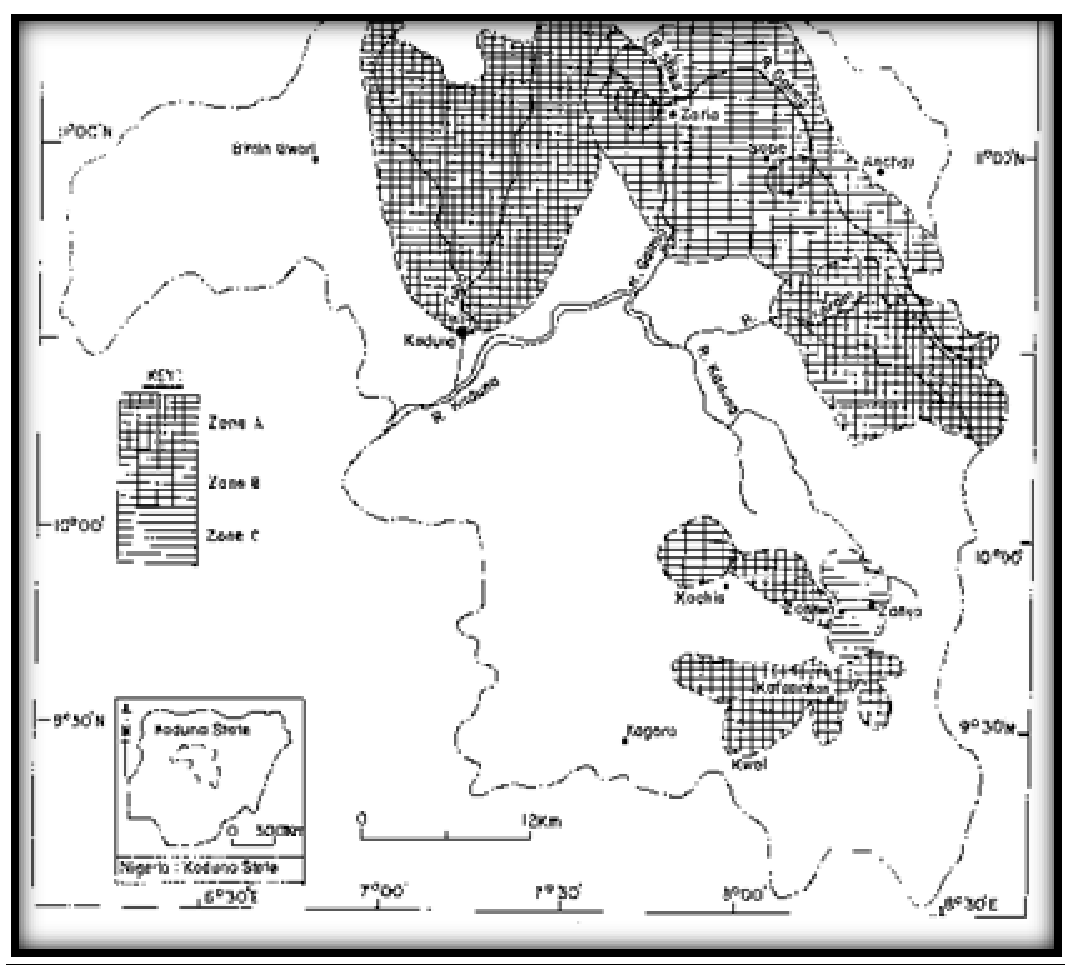

Figure 4b. Pattern of Subsurface Flow
Zone-A: Extremely Hugh Contribution.

Zone-B: High Contribution

Zone-C: Moderate Contribution

Zone-D: Average Contribution

Zone-E: Low Contribution

Zone-F: Extremely Low Contribution

Zone -A: High Contribution

Zone-B: Moderate contribution

Zone $-\mathrm{C}$ : Low Contribution 


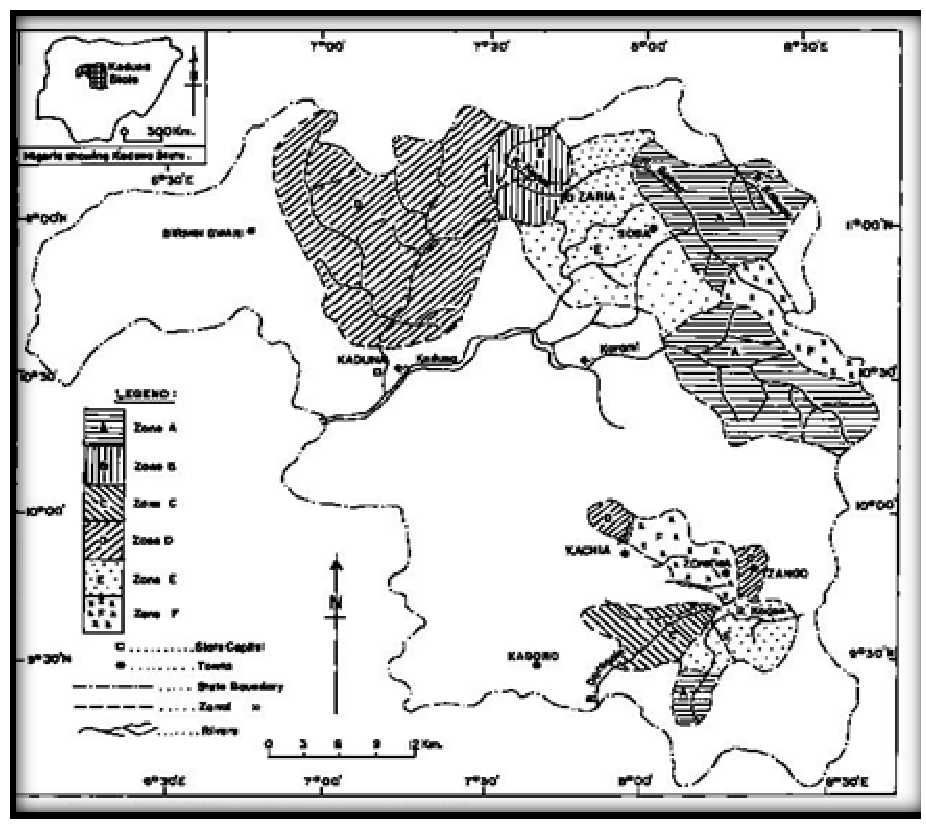

Zone-A: Extremely High Contribution Zone-B: High Contribution Zone-C: Moderate Contribution Zone-D: Average Contribution Zone-E: Low Contribution Zone-F: Extremely Low Contribution.

Figure 4c. Pattern of Groundwater Flow 